This is the peer reviewed version of the following article: Bolton, S., and Skountridaki, L. (2017) The Medical Tourist and a Political Economy of Care.Antipode, 49: 499-516, which has been published in final form at https://doi.org/10.1111/anti.12273. This article may be used for non-commercial purposes in accordance With Wiley Terms and Conditions for self-archiving. 


\title{
The Medical Tourist and a Political Economy of Care
}

\author{
Sharon Bolton
}

Lila Skountridaki

Stirling Management School

\begin{abstract}
Medical tourism has gained prominence in academic, policy and business arenas in describing the growth in the number of people travelling outside of their home country to receive planned medical treatment, with the emphasis on the combination of addressing pressing health concerns with a leisure trip. This conceptual essay offers insights into how patients are being reconceptualised in a neo- liberal setting as medical tourists. In so doing it offers two key contributions. First it offers a deeper theorisation of trends in international healthcare through a political economy of care framework. This framework is not only focused on human interaction and experience but also on the political, economic and social space in which human life is played out. Second, it offers new insights into the exploration of human relationships within a market economy so that the medical tourist is seen with new eyes as a relational being.
\end{abstract}

Keywords: Medical travel, medical tourism; political economy of care, market dynamics, relationality, embeddedness

\section{INTRODUCTION}

Medical tourism has gained prominence in academic, policy and business arenas in describing the growth in the number of people travelling outside of their home country to receive planned medical treatment, with the emphasis on the combination of addressing pressing health concerns with a leisure trip (Connell, 2006; Horowitz et al., 2007; Kumar, 2009; Hall, 2011; Musa et al., 2011; Buzinde and Yarnal, 2012). Often, such trips may be for minor cosmetic procedures or diagnostic tests in which health risks are relatively low (Cook, 2008; Wilson, 2011). Frequently, however, procedures undertaken abroad include major 
interventions, such as orthopaedic surgery, cardiac care/surgery, cancer treatment and fertility treatment (Eissler, 2010; Johnston et al. 2012). Whatever the treatment required, receiving healthcare abroad is complex; requiring orchestrated coordination of a range of services. For the medical tourist, commitment to travel to satisfy healthcare needs involves high levels of emotional engagement combined with a rational-consumerist problem solving approach.

Amongst recognition of the dominant business focus there is also a growing critical chorus that highlights the tensions inherent in the terminology of the medical tourist as a means of capturing the dynamics of the expanding international healthcare market and its impact upon those consuming its services. There are a range of observations; for example, the bulk of currently available literature captures only the supply side and ignores the perspective of the travelling patient (Kangas, 2011: 328), there is insufficient scrutiny concerning the nature of the practice associated with medical tourism (Bergmann, 2011), there is an underestimation of the complexities involved in becoming globally mobile (Cohen, 2012), and the marketing of medical services offered is over-glamorised and downplays health risks (Viladrich and BaronFaust, 2014). The discussion is rapidly accelerating, with more and more academic literature from a range of disciplines embracing a critical dialogue and inviting further debate. Nevertheless, despite the notion of commercialisation, choice and extended care being explored in different ways (Connell, 2011; Hall, 2011; Viladrich and Baron-Faust 2014), the debate remains under-theorised. In this paper, we interrogate the concept of the medical tourist as an individual who is autonomous, free, and able to rationally choose where, when, and how they wish to receive medical care.

A political economy of care is presented as a conceptual framework where human connection, rather than market logic, is a priori. Our conceptualisation of the medical tourist rests upon a relational ontology that assumes dependency and vulnerability is a universal and inevitable part of the human condition (Held, 2006; Fineman, 2004; Kittay, 1999; Lynch et al., 2009). It is, therefore, something of a surprise to find the globalisation of the healthcare market and the presentation of the medical tourist as a cross-border healthcare seeker (Glinos et al, 2010; Horton and Cole, 2011; Mainil et al., 2012), does not account for such dependency more. After all, it is widely recognised that any system of exchange (indeed, any market system) relies on both paid and unpaid dependency work carried out in the public and private spheres. The operationalisation of the political economy of care framework rests upon this foundational normative understanding. It reveals how the medical tourist is not autonomous 
but interdependent with, and reliant upon, other systems that provide both material and nonmaterial webs of support: the state and the family, for example (Caton, 2012; Granovetter, 1985; Polanyi, 1957; Streeck, 2011). Yet the dominant use of the term medical tourist to describe people seeking healthcare away from their home country is acting as a powerful discursive device that masks the relationality and connection involved in the giving and receiving of (health) care. It is suggested that the relational ontology that lies at the heart of a political economy of care reveals the long-term consequences of ruptured relationships and an emotional and material deficit that cannot be filled by the market.

This conceptual essay offers insights into how patients are being reconceptualised in a neoliberal setting as medical tourists. In so doing it offers two key contributions. First it offers a deeper theorisation of trends in international healthcare through a political economy of care framework. This framework is not only focused on human interaction and experience but also on the political and economic space in which human life is played out (Fletcher, 2011; Su et al., 2013; Tribe, 2009, 2010). Second, it offers an approach to exploring human relationships within a market economy that views the medical tourist with new eyes: not merely as a rational, market actor but as a relational being.

\section{A POLITICAL ECONOMY OF CARE}

The relational ontology that underpins the analytical framework of a political economy of care, as presented here, draws on feminist thought in the areas of an 'ethic of care' (Gilligan, 1982; Held, 2006; Kitttay, 1999; Kittay and Feder, 2002; Sander-Staudt, 2006; Tronto, 1993), 'affective equality' (Lynch et al., 2009), theories of vulnerability and dependency (Fineman, 2004; Kittay and Feder, 2002) and the complementary concept of embededdness (Granovetter, 1985; Polanyi, 1957; Streeck, 2011). The literature in these areas is wide and varied in its approach; ranging from a focus on gendered psychologies (Gilligan 1982), to an emphasis on the nature of care and its execution (Kittay, 1999; Lynch et al., 2009), to a call for introducing care ethics into a range of different disciplines, including business and management (Gabriel, 2009) and human geography (Lawson, 2009), to a broader political economy approach to understanding, not only the division of labour in care work, but also how a capitalist economy does not account for the vital role the care of others plays in sustaining economy and society (Buebeck, 2002; Fineman, 2004; Held, 2006; Marx and Engels, 2005; Polanyi, 1957; SanderStaudt, 2006; Sayer, 2011; Tronto, 1993; Yeates, 2012). Despite the range of voices and ongoing debate within these different, but closely related, fields of study, there remains a 
common focus on social relations and the social practices and values that sustain them.

For feminists interested in promoting a relational understanding of political economy there are three foundational myths upon which a market society is built: autonomy, independence, and self-sufficiency. As concepts they represent complementary ways to think about individuals, and their position in society, and are often grouped together to present the image of someone who is free (autonomous), self-reliant (independent) and, hence, materially provided for (self-sufficient) (Fineman, 2004; Held, 2006; Tronto, 1995). Critique is focused on the way thinking about human development has become conceptually crippled by the political rhetoric of the individual subject (individual autonomy and responsibility). This individuality is understood in the narrowest sense - as being responsible for oneself and direct dependents. It is also focused on economic responsibility. Driven by, what Nussbaum describes as, a 'fiction of complete adulthood' (Nussbaum, 2001: 189), policy is developed on the basis of the Lockean principle of people being 'free, equal and independent' (Locke, 1689). In this scenario, liberal social contracts between individuals, individual and state, and individuals and institutions are developed based on reciprocity between rough equals. This individuality creates freedom; freedom from reliance on the state but also freedom from interference by the state. There is no place to account for difference and degrees of vulnerability. Any dependency work, therefore, is relegated to the family arena and unaccounted for (Fineman, 2004; Held, 2006; Lynch et al., 2009).

It is of little surprise that the implicit reliance on the family (viewed by feminists as an inherently hierarchal, gendered, unequal and abusive institution) as a shelter for the vulnerable and as providers of care and concern gives rise to feminist critique (Nussbaum, 2001; Fineman, 2004; Roestone Collective, 2014). The family and women's work within it is essential in maintaining the myth that autonomy can be maintained (Fineman, 2005; Held, 2006; Tronto, 1993). Indeed, Carole Gilligan's seminal contribution, 'in a different voice', proposes that women undergo a different moral development based on care and compassion for others, rather than a male model of reason and rules. In this way the gendered division of care work labour is continually reproduced according to supposed 'natural' abilities. Debate has raged concerning an overly simplified divide between an ethic of care (feminine) and an ethic of justice (masculine). Ethics of care is an approach often used to emphasise the importance of caring relationships (Held 2006; Kittay 1999). It underlines the necessity of responding to the needs of those who are dependent upon us. Advocates of an ethics of care create a strong chorus of concern for the dominate view of a rational utility seeking individual associated with Kantian ethics. It is Martha Fineman, however, who truly reconciles the ethic 
of care and ethic of justice dichotomy with her understanding of the vulnerable subject (Fineman, 2008):

'I want to claim the term 'vulnerable' for its potential in describing a universal, inevitable, enduring aspect of the human condition that must be at the heart of our concept of social and state responsibility ..........Vulnerability raises new issues, poses different questions, and opens up new avenues for critical exploration ......' (Fineman, 2008: 5).

Fineman targets her empirical critique on material inequalities present in contemporary society; her observations of the removal of a state provided safety net that ensures fundamental 'resources and dignity' core to being human (Fineman, 2004: 11) resonates across neo-liberal, western economies.

Dependency, then, is a central concern for feminist thought and an ethic of care approach: in every part of society it is women who carry the burden of dependency work (Fineman, 2004; Kittay, 1999; Kittay and Feder, 2006). Neo-liberalism's superficially gender neutral doctrine assigns dependency and vulnerability to the domestic realm to be taken care of by an army of women (as part of paid and unpaid labour processes) in the home (Bolton, 2009; Tronto, 1993). In a similar vein, feminists have demonstrated that 'caring' is not a natural activity: 'It is thoughtful, intentional work' (Kittay and Feder, 2002: 3) that is grounded in a 'material, relationist approach' to productive labour (Yeates, 2012). An ethic of care, however, emphasises care as a moral activity that offers an alternative to the model of social and political life based on autonomous and equal agents. It recognises that we may care for (attending to the material needs of another) or about (attending to material and emotional needs with a sense of involvement and development of an affective bond) but that both approaches to caring acknowledge human connection and dependency (Lynch et al., 2009). Dependency is asserted as universal and inevitable (Fineman, 2008) and understood as complex and multi-faceted taking many different forms and developing differently over time - psychological, physical, emotional, and economic. People are, therefore, embedded in 'relationships of dependency' (Kittay, 1999).

Ethics of care is described as a moral theory. However, it is not based in abstract theorising about individual reflections on what may be evaluated as right or wrong but in an approach rooted in relationality and humanity's reliance on the practice of caring relationships - whether these relationships are with other individuals, family, institutions or the state (Held, 2006; Sander-Staut, 2006; Tronto, 1995). It celebrates people's capacity to be emotionally involved and, hence, morally outraged. Reflections on important issues cannot be based on 
reason alone (Held, 2006). Nevertheless, ethics of care has been widely criticised on a number of levels: for dissolving into moral relativity; for presenting the potential to be anti-feminist because it holds the danger of elevating one sided care to a natural attribute of women (Hassan, 2008; McClaren, 2001); and that as a singular concept it is 'over-burdened' as an analytical tool (Halwani, 2003).

Whatever the debates concerning an ethic of care, it has successfully brought attention to how people sustain fragile human connections that allow them to grow and prosper (Gabriel, 2009). Its critics underestimate its explanatory power and neglect that care is a concept that includes the full spectrum of human relations offering profound insights into moral, political and economic life (Held, 2006; Sander-Staudt, 2006; Slote, 1998; Tronto, 1995). It is true that a relational ontology does not always offer clear connections to understanding the dynamics of a market economy, instead emphasising sensitivity to the multiple contexts and motives that shape caring activities/ relations. However, it does hold a universal and very simple normative value; that of understanding how caring relations run through society, providing the connective tissue between the state, economy, institution and individual. In turn this can be further supported by the complementary notion of embeddedness so that the relational aspects of an ethics of care become firmly integrated into a political economy of care. Granovetter presents actors and economic practices as 'embedded in concrete, ongoing systems of social relations' (1985: 4). An approach established by Polanyi (1957) in the way he highlights the web of social, moral and economic dimensions that oils the wheels of modern market societies. It has long been recognised that a sustainable market economy is necessarily underpinned by a social, political and moral sphere (Marx and Engels, 2005; Sayer, 2011; Streeck, 2011). Hence, a political economy of care rests on an understanding of behaviour in markets as influenced at the micro level of social relations and at the macro level by institutional frameworks and norms and values in society (Block, 1990; Beckert, 2009; Krippner and Granovetter, 2004).

Virginia Held and Joan Tronto are particularly successfully in elaborating how care is an embedded and necessary part of all aspects of human life. The strength of the approach is that it illuminates the importance of caring relations as being relevant not only to friends and family but to politics and policy, the organisation of markets, and social life (Connolly Carmalt, 2010). In this way the notion of relationality is firmly placed within institutionalised structures that may enable or constrain the capacity to flourish; in every sense: as individuals and communities. The relational ontology that underpins a political economy of care endorses the need to understand the vulnerability inherent in every human being. It under-mines the 
notion of the autonomous, rational, utility-seeking individual and displays people as reliant, reflective, reciprocal agents who require support and a safe space in order that they may flourish. Such support will be delivered via caring relationships that feed into a broader system of just distribution of opportunities and rewards. Thus, the creation of safe spaces is a dynamic and uneven process, that produces care in a variety of forms dependent on context and relationships formed (Roestone Collective, 2014). Political economy of care is presented here as an analytical framework that offers the means to understand individual vulnerability and dependency, whilst revealing the connecting tissue that binds people to spaces, communities and institutions that are firmly situated within market and state dynamics. The same framework acts as a normative statement in that it highlights how a roaming, unbridled market potentially severs such connections and renders the medical tourist a vulnerable subject. A critical review of contemporary literature highlights the changing political economy of healthcare and the emergence of the concept of the medical tourist. A growing critical chorus exposes some of the incongruences of applying the term medical tourist to individuals seeking healthcare and begins to lay bare the human frailties involved. A political economy of care framework expands this growing understanding by firmly placing an analysis of the medical tourist within economic, political and social contexts that reveal the full spectrum of human relations.

\section{THE POLITICAL ECONOMY OF THE MEDICAL TOURIST}

The term 'medical tourist' has been adopted by various practitioner stakeholders and academic scholars and is particularly relevant to the academic and business field of tourism and hospitality. Indeed, writers from the tourism discipline have approached medical travel as a new facet of tourism and thus the term medical tourist has become a dominant descriptive device (Connell, 2006: 1093, 2011) so that healthcare providers, travel facilitators, as well as whole states whose governments support the development of the sector as strategic for the national economy, employ the same term. Nevertheless, there is discontent with the term tourist being applied to people seeking healthcare abroad. For example, Bergmann (2011) and Glinos et al. (2010) suggest that the term medical tourism is inadequate to refer to the scope for which people travel abroad seeking healthcare. Whilst Bergmann (2011: 282) highlights how the term tourism 'masks the fact that (...) there is a wide range of motives for travelling to another country for treatment'. Similarly, Glinos et al. (2010) propose that medical tourism as a term is too narrow to capture all situations under which people are provided healthcare in 
another country. Rather, they recommend the term patient mobility.

Other commentators express concern for the consumer experience and dispute the validity of the concept of the medical tourist, irrespective of the motivation to travel, as it implies 'a leisurely, pleasurable activity undertaken by people, often with their families, on a vacation' (Garud, 2005: 318). Kangas highlights that the term obscures the hardships involved in the trip (Kangas, 2011: 328). She also emphasises the elevation of the commercial over care in the way medical tourism 'prioritizes the (...) destinations and facilitators over the patients' (Kangas, 2011, 328) as entire countries seek to market themselves as medical tourism destinations. Niechavej and Frame (2012), for example, suggest that facilitators bundle medical and tourism services together, referring to the practice as tourism, and cultivate the impression that patients travelling for healthcare combine their treatment with vacation. Nevertheless, most often the trip is short and medical tourists 'see only a glimpse of the country of destination' (Niechavej and Frame, 2012: 203). Johnston et al. (2013) explain that even when planned, tourism activities post-operatively often do not take place; medical tourists may be in pain or may feel homesick and desire a speedy return home. The tourism component of the trip, therefore, is marginal (Cohen, 2012: 169).

Travelling to another country involves the function of the hospitality sector by default; travel costs, accommodation, in addition to goods consumed, boosts the tourism sector of the economy. That does not mean, however, that tourism becomes the dominant feature of the activity. With some irony, Matorras (2005: 3571) notes that no one refers to immigration as 'labour tourism'. Based on qualitative interviews with people travelling from the US abroad for healthcare, Eissler concludes that

'the use of the term "medical tourism" deemphasizes the significance that the study participants placed on the basic healthcare needs, economic considerations, and dissatisfaction with the ability to obtain health in the US that motivated these health seekers to travel internationally for medical care' (Eissler, 2010: 108-9).

What emerges from the wealth of varied literature that covers the topic is that the term medical tourist successfully represents the practice of marketing commercial health services (Lunt et al., 2011) whilst misleadingly implying a 'hint' of a pleasurable experience (Connell, $2011 ; 2015)$. In terms of combining a decision to travel for medical treatment with a wish to also experience relaxation, recreation, cultural stimulation and joy, i.e. acting as a medical tourist, research indicates that aspiration does not always match outcome and there is evidence to suggest both positive and negative personal experience. Ackerman (2010), for example, tells us how post-operative patients, who have undergone aesthetic surgery in Costa 
Rica and stay in the same lodge, create small communities and offer strong psychological support to one another. On the other hand, other patients in the same study express high levels of anxiety about post-operative pain, feel uncomfortable, and regret having the procedure and recovery period far from home and loved ones (Ackerman, 2010). Arguably, medical tourists experience stress and fear and encounter highly sensitive situations that tourists (generally) do not. Anxiety stems largely from being in a foreign environment, often of a developing country (Eissler, 2010; Johnston et al., 2012). The situation in the latter becomes more frustrating when patients face financial constraints or other difficulties but have no other option. Eissler (2010: 42) notes that all 15 patients she interviewed had unsatisfied medical needs that caused discomfort and had an impact on their ability to work and enjoy life.

Clearly there are diverse realities that the term medical tourist cannot capture. The term 'tourist' denotes the ability to travel the world to sample the wares of the healthcare market. It is interesting to note that it is the medical tourist who dominates discussion and not the health tourist, thus offering scope for major medical procedures to be involved and not merely travel for rest and recuperation (Hall, 2011). The savvy patient-consumer is presented as an informed individual that compares providers' services and prices in a number of locations and purchases the best deal for healthcare. The decision making process can be compared with tourism decision making, where the individual decides on destination and provider without any type of professional assistance as a necessary prerequisite. This implies even greater freedom to the market and, of course, greater choice to the consumer. Gilmartin and White (2011: 276) highlight that 'the use of the term 'tourism' to describe this international movement in search of healthcare emphasises individual agency, choice, and possibility, [...] and celebrates the emancipatory potential of mobility'. In that context the citizen becomes mobile and is emancipated from state intervention/regulation; and 'passive patients' are transformed into 'empowered educated consumers' (Ormond and Sothern, 2012: 935).

The term medical tourist directs attention to the individual and simultaneously diverts attention from the broader politico-economic trends, concealing the context within which transnational healthcare takes place, the diversity inherent in the internationalised health care market and services offered, and the motivations that underpin health-seekers decisionmaking processes. For example, there is a significant, and often under-recognised, variety in the seriousness of interventions undertaken abroad (Cook, 2008; Smith-Morris and Manderson, 2010). Diversity in international patient movement is understood in a myriad of ways: long distance trips are distinguished from shorter ones occurring across regions close to national borders (Bell et al., 2015; Glinos et al., 2010) and flows are often conceptualised 
with regards to directionality which focuses on the distinction of countries into core and periphery; from advanced to middle/low income economies (Global North to Global South); from middle/low income to middle/low income countries (Global South to Global South); in addition to the well-established pattern of patient flowing to advanced economies (Global South to Global North) (Crush et al., 2012; Crush and Chikanda, 2015; Ormond, 2015; Bell et al., 2015). Patient movement is also most often discussed with respect to the motivations lying behind patient decision making. Several drivers are recognised: high treatment costs that make treatments unaffordable at home (Arellano, 2007; Barrowman et al., 2010; Carrera and Lunt, 2010; Connell, 2006; Cortez, 2008; Glinos et al., 2010; Svantesson, 2008); unavailable treatments due to long waiting lists (Barrowman et al., 2010; Carrera and Lunt, 2010; Connell, 2006; Cortez, 2008; Glinos et al., 2010; Svantesson, 2008); legal restrictions (Carrera and Lunt, 2010; Connell, 2006; Cortez, 2008; Glinos et al., 2010; Svantesson, 2008), familiarity with destination country for diaspora members, expatriates (Glinos et al., 2010) or migrants (Brown, 2008; Hanefeld, et al., 2015); domestic limitations in technology, training, or infrastructure (Carrera and Lunt, 2010; Connell, 2006; Cortez, 2008); ease and low cost of travelling and privacy reasons (Arellano, 2007; Carrera and Lunt, 2010; Connell, 2006; Turner, 2008). Media reports and internet portals provide evidence, for example, of Americans and Canadians moving to Asian or Latin American countries for cheaper dental care; cosmetic surgery (Ackerman, 2010); timely orthopaedic surgery (hip/knee replacement) (Johnston et al., 2012); accessible fertility treatment and diagnosis tests (Eissler, 2010); affordable cardiovascular surgery; or even experimental stem cell treatment (Song, 2010). Similarly, European citizens travel to Eastern Europe, Southern Europe and Asia for cosmetic procedures such as aesthetic surgery (Bell et al., 2011), fertility treatment (McKelvey David, Shenfield and Jauniaux, 2009), but also major medical procedures (Crush et al., 2012; Holliday and Elfving-Hwang 2012).

Fewer arguments are examined in the literature from a wider perspective, where most of the basic drivers are framed as weaknesses of national healthcare systems (Garcia-Altes, 2005). This in itself is not a new phenomenon; limitations of local healthcare providers have always led patients with the means to travel to seek healthcare abroad. However, in the context of the shrinking of state support for health services in the wealthier west, more citizens from different social strata, from both developing and advanced economies, are deciding to travel around the world to satisfy health needs. Holliday et al. (2011) and Perfetto and Dholakia (2010) draw attention to the middle/low socio-economic background of Europeans and Americans, respectively; while Ormond and Sulianti (2014) and Bochaton 
(2015) note that the choice of Thai provider depends on the socio-economic background of patients from neighbouring countries with both disadvantaged and wealthier Indonesians and Laotians, respectively, travelling for care according to financial means.

In response to increasing international demand for cross-border care, a number of governments see an opportunity in developing a 'medical tourism' sector. The cycle of commercialisation reinforcing globalisation and the reverse is then accentuated (Wallerstein, 1974). In order to successfully globalise, measures which strengthen the commercial character of healthcare provision are implemented (Chee, 2007). For example, Malaysia relaxed the advertising restrictions imposed upon healthcare providers, set quality benchmarks for clinics, promoted healthcare services to foreigners and directed attention to 'consumer choice' (Chee, 2007: 23-4). Ormond (2013) suggests that in Malaysia, 'medical tourism' is a facet of the evolving neoliberal policies and privatisation efforts of the last three decades.

It becomes clear that a growing medical tourism market is realised within a neo-liberal space where principles of universal access to healthcare and state responsibility are increasingly put aside. For example, Lee (2012) highlights the contradiction between the principles of universal coverage and commoditised healthcare provision simultaneously promoted by the Costa Rican authorities. At the same time, Arnold (2005) suggests that international trade is not an inevitable outcome of advanced technology and improved communication and transportation systems but is deliberately fostered by key institutional actors such as multinational corporations and industry trade lobbies through international regulatory bodies and trade agreements. The General Agreement on Trade in Services and specifically the Trade in Health Services agreement is part of the World Trade Organisation's agenda promoting global healthcare markets. Similarly, the European Union (EU) encourages cross border care within member states under the logic of a common market. Arguably, the globalisation of healthcare provides fertile ground for the transformation of health into a commodity; of healthcare provision into trade in services; of hospitals into commercial organisations focused on exports; of medical professionals into entrepreneurs (Skountridaki, 2015); and patients into consumers (Ormond and Sothern, 2012: 935) or, more specifically, tourists.

Furthermore, advancing privatisation has negative consequences for health equity and the aspiration to 'protect the human right to health' at an international level (Adams et al., 2013). Analysing patient movement through a political economy lens, Wilson (2011) notes that current discussions ignore the social class dimension and highlights how current discussion fails to include patients who cannot access healthcare either at home or abroad and 
focuses on the 'global elite'. Similarly, in consideration of patients who cannot travel to address their healthcare needs, a postcolonial conceptual lens highlights aspects of exclusion and inequality (Buzinde and Yarnal, 2012) at the international level. This is most relevant with regards to populations in periphery regions that cannot access healthcare offered through the market to foreigners.

The globalisation of healthcare provision has attracted multidisciplinary interest, thus creating a plethora of terms to describe the activity of travelling out of one's own country to seek healthcare, i.e. patient mobility, medical outsourcing, medical travel, consumption of health services abroad, cross-border care, and health tourism. Nevertheless, the terms medical tourism and medical tourist now dominate discussion and have become the most common descriptive term to capture a range of motivations to travel for healthcare. Whilst travelling to receive healthcare abroad may be a pleasurable experience for many, without understanding individual motivations to travel, the range and scope of different procedures and people's capacities to engage and recover from procedures, it becomes apparent that the term tourism can be misleading; distorting the real nature of medical travel in the eyes of (potential) patients; and removing the humanity involved in the giving and receiving of healthcare.

\section{THE MEDICAL TOURIST AND A POLITICAL ECONOMY OF CARE}

Our analysis suggests that the 'medical tourist' exemplifies the widespread acceptance of the market in healthcare and the individualisation of those seeking healthcare. The medical tourist conceals that the patient is trapped in a public/private dichotomy: the public world of the international healthcare market and the private world of unpaid care. We offer here a holistic frame where we understand consumers of health services as relational and vulnerable beings moving in and between both public and private spaces. By this we do not detract from the differences and importance of economic inequality, the urgency of the medical condition, or the differences in access to decent healthcare. Rather, the framework transcends the diversity inherent in discussion of international medical tourism and encompasses high/low risk; elective or medically necessary procedures; variation in motivation, directionality or social class and brings together a variety of concerns over the globalisation of healthcare (Buzinde and Yarnal, 2012; Ormond, 2015; Wilson, 2011). As such, we look into the common experiences of receiving care: first, in the absence of formal protection typically provided through regulation and guaranteed social rights (most often in countries in the core than the periphery), and second, in the absence of informal protection often secured through institutional and intimate connections at home. 
For our conceptual essay a political economy of care offers the analytical thread to show how the medical tourist is connected to others, to the state and to the market. In particular, the connection to the state and relational networks is weakening as people are increasingly pushed to make individualised choices within a market paradigm and yet, paradoxically, with a reliance on support and care offered in the private space of personal finance and relationships. These dynamic connections and disconnections create analytical complexity as the public and private increasingly bleed into one another under a market logic revealing, through the lens of a political economy of care, the failures of a contractual model for life in and out of the private realm.

\section{The state, the market and dual disconnection}

Medical tourism may be but one term of many to describe the way people now move more freely to seek an answer to their healthcare needs; however, it is the term that has gained most currency. It is proposed that its popularity is not a linguistic accident but rests with the market paradigm upon which medical tourism relies. Despite the growing critical chorus concerning the vulnerabilities faced by medical travellers (Garud, 2005 Kangas, 2011; Eissler, 2010; Johnston et al., 2012), the medical tourist rhetorically represents a 'mobile body' who is autonomous and free to make their own choices about who should treat them, how the treatment should proceed and where it should take place (Ormond and Sothern, 2012; Wilson, 2011). However, in the medical tourist literature, despite a recognition of push factors, there appears little recognition that 'choice' takes place within historical, cultural, political and economic influences and understandings so that people's decision making is manoeuvred into certain channels that actually limit, rather than extend, options (Fineman, 2008). For example, the withdrawal of publicly funded healthcare and the rhetoric of long waiting lists push people to make a choice to travel for medical care for fear of long term health implications (Ormond, 2015). It is not a case of 'push' factors creating a new platform for positive choices to be made but that people fear the consequences if they do not seek healthcare elsewhere (Hopkins, 2013). Thus, responsibility is taken from the state and passed to the individual in what Fineman describes as a 'dependency deficit' (Fineman, 2004). This is especially the case when the growing discourse in the policy realm is entirely negative towards those who are dependent on the state (Fineman, 2005; Lynch et al., 2009).

Individualisation of responsibility is not new but has become a dominant discourse (Malpass et al., 2007; Langley, 2007). In particular, health risks are increasingly perceived within the sphere of private life and their individualisation is reinforced by a number of 
'socio-cultural practices such as the growth of the fitness industry, self-help publishing, and lifestyle media' (Malpass et al., 2007: 231). Arguably, medical tourism exemplifies the individualisation of responsibility as a practice which showcases health problems and an international search for their solution as 'the healthcare project' of an individual (Ormond 2015). It is emphasised here again that this personalised responsibility is particularly demanding for individuals (Malpass et al., 2007: 23). Patients have to dedicate time, thought, emotions, and resources to plan and execute the trip. And yet, according to economic analysis, health risk is so high for individuals that the organisation of healthcare merits a collective response instead of being left to the rules of individualised market mechanisms (Stiglitz, 2009). In the mid $20^{\text {th }}$ century, in response to market failures in the healthcare sector, which leave particularly the poorest unprotected, governments took action to relieve people from uncertainty and mitigate inequality in access to healthcare (Doyal, 1979; Wallerstein, 1974). Increasing marketisation over the past forty years, and its accentuation through trade, however, reverses the above rationale; severs dependency on the state and increases vulnerability (Wallerstein, 2002).

Our analysis highlights that when a patient travels abroad seeking healthcare her vulnerability is unavoidably accentuated. Not only is she separated from her care networks, i.e. family and friends and, more formally, the familiar access routes to advice, support and intervention on health issues, but she may not be eligible for compensation in case of malpractice, she may face hardships in suing suppliers due to language and cultural barriers, or may be unaware of the regulatory framework and local customs. For example, Cortez (2008) highlights that, when American citizens travel overseas for medical care, they essentially waive their rights and protections. While patients are assumed as able to take decisions on their healthcare with limited or no (medical professional) assistance (Gilmartin and White 2011: 276), their capacity to do so is undermined by deceptive online information about foreign providers. In their decision making process, empirical research shows that patients often consult facilitators' websites; yet, given the commercial character and marketing focus of the supply side, in combination with a lack of regulation, a significant number of such websites tend to emphasise benefits and downplay the risks of travelling for care (Mason and Wright, 2011; Sobo et al., 2011; Penney et al., 2011). We cannot understand the medical tourist, therefore, without recognising their deeply embedded position in a web of relationships and the hidden costs of a dual disconnection that occurs within the framework of individual choice. Entering the international healthcare market creates new forms of vulnerabilities as connections to public and private sources of support are eroded. 


\section{Dependency and re-connection}

A central characteristic of a political economy of care is how it conceives of personhood. That is, people are relational, vulnerable and dependent on others. Similarly, medical tourists are not the self-sufficient, rational individuals as presented in liberal political and economic theory and, by association, business literatures and guide books that promote medical tourism (Ormond and Sothern, 2012). People do act and think independently but as part of a dense web of social relations.

To see people as individual atoms, who are free, and free to choose associations and courses of action, is to assume they can be free-floating; disembedded from norms, values and community at will (Fineman, 2004; Held, 2006; Kittay, 1999). Such an impoverished picture of humanity is far removed from what we understand as a logic of care and the reality of lives that are dependent on others (Mol, 2008; Sayer, 2011). This is ever more evident when people are physically and emotionally vulnerable due to illness or after a medical intervention. Various evidence illustrates the prevalence of such embeddedness in all phases of the trip when seeking care abroad. The decision to travel relies on people developing, deploying, or denouncing social systems which guide them to seek healthcare abroad. People in Indonesia, for example, count on financial and emotional support along with valuable information provided by their social networks to travel (Ormond, 2015). Similarly, Laotians travelling to Thailand gain information from family and friends and often financial support from (international) family connections (Bochaton, 2015). And residents of more advanced countries, rely on relationships that are often commercial (travel facilitators, doctor referral networks) (Hanefeld et al., 2015). Subsequently, medical tourism involves the movement of the patient out of their social environment. Though family members may desire to escort the patient abroad for support, they face difficulties due to prohibitive travel costs or commitments 'at home.' Inhorn and Shrivastav (2010) describe, for example, how career couples who have to travel abroad for fertility treatment face significant obstacles to travel together. They both need to take days off from work simultaneously, which is often difficult, especially as they wish to keep the reasons private. Hopkins (2013) describes how she depended upon the coordinated involvement of her daughters sharing the responsibility to drive and escort her to the US to undertake bariatric surgery. Rich empirical studies that explore the actions of and outcomes for medical tourists highlight how, when familiar care networks are post-operatively missing, people become anxious (Eissler, 2010) and, where possible, attempt to establish new communities of mutual care and psychological support 
(Ackerman, 2010). It becomes obvious that dependency follows the medical tourist in all phases of her individual 'healthcare project'. Either through a deficit in formal and informal care networks or through the attempt to form care network substitutes. Human dependency is a reality manifested during the organisation of the trip, its realisation and the embodiment of the treatment, or even upon return. After all, who cares for the medical tourist when they return home without follow up treatment or the time and financial resources for proper convalescence? There is evidence to suggest that some medical providers in North America deny responsibility or are hostile to patients who receive overseas treatment. The discourse of joy and pleasure haunts the medical tourist; for example, there are reported cases of medical doctors in the US denying care to patients with post-operative complications (Eissler, 2010) and in Canada some patients appear unwilling to discuss with their doctor the trip abroad for fear that they will be judgmental about their decision (Johnston et al., 2012). In this scenario it might be claimed that 'market institutions are 'free-riders' appropriating the labour of the caretaker for their own purposes' (Fineman, 2004: xvii) displaying the dynamics of dependency as it moves between the public sphere and the private realm.

A review of critical studies on medical tourism highlight the hardships involved, the supply-side orientation, the minimal role of tourism activities and the frustration of patients. It is important to note, however, that the analysis presented here through the political economy of care becomes important as it highlights the healthcare market as an 'instituted process' (Polanyi, 1957) that is characterised by both economic and non-economic institutions in public and private spaces which perform specific social functions and possess particular social histories. As such it offers a holistic frame and, thus, deeper theorisation of people's vulnerability within the international health care market. Our approach reconceptualises people moving between different institutions as they seek and receive healthcare across borders and sheds new light on how we might view the medical tourist as a vulnerable subject who is dependent on others in a myriad of ways. A political economy of care shifts the frame of analysis away from a market paradigm and renews the possibility of different social and economic arrangements according to different values and visions.

\section{REFLECTIONS}

The analysis presented here utilises a political economy of care as a means of unpicking the implicit assumptions of the notion of the medical tourist. We suggest that medical tourism is not a benign descriptive term but a rhetorical device that is loaded with meaning. When the 
medical tourist is firmly placed within economic, political and social contexts and influential institutions' agendas for the widespread globalisation of healthcare delivery, the normative assumptions that lie behind the term are revealed so that the medical tourist emerges as an individualised model of homo economicus; moved into the public space of commercial healthcare and consumer choice and disembedded from the private space of care networks. Further exploration through the lens of political economy of care reveals this as a fallacy and exposes the medical tourist as a vulnerable human being, not merely as a rational, maximum utility seeking individual. Such human vulnerability is understood in the context of belonging to a web of social relationships and safe spaces that offer primary and secondary care. This intricate web may include home based networks of state provided care arrangements that might not be available to those returning from receiving treatment abroad. It may also include the embedded caring activity of personal relationships that we rely upon as part of an overall health treatment package.

Of course, there is an argument to suggest that some treatments are superficial and not always necessary for health reasons - aesthetic procedures, for example - hence, they can readily be combined with a trip for leisure. There are also questions over terminology and that health and medical tourism may denote different things. Nevertheless, it is the assumptions that lie behind the terminology that are important; not only for what they include in terms of individual consumer choice, but also for what they neglect in terms of human vulnerability and dependency.

Alternative descriptive devices may be suggested that better reflect the rapidly developing movement of patients across the globe: medical immigration (Crush et al., 2012), medical exile (Inhorn and Shrivastav, 2010), medical pilgrims (Song, 2010), health seeking travel/traveller (Eissler, 2010), international medical journeys (Kangas, 2011) or medical travel. This would not, however, change the lived experience for the thousands who travel abroad seeking medical care unless there is a matched understanding that healthcare cannot be entirely marketised; as with any market, it relies on state interventions to correct the market failures and mitigate the related impact on inequality, social cohesion and human flourishing (Polanyi, 1957; Stiglitz, 1999; Streeck, 2011). It also rests within relationships of dependency that provide human connection and commitment that, quite simply, are not for sale.

\section{REFERENCES}


Ackerman, L.S. (2010). Plastic Paradise: Transforming Bodies and Selves in Costa Rica's Cosmetic Surgery Tourism Industry. Medical Anthropology: Cross-Cultural Studies in Health and Illness, 29, 4, 403-423.

Adams, K., Snyder, J., Crooks, V.A and Johnston, R. (2013). Promoting social responsibility amongst health care users: Medical tourists' perspectives on an information sheet regarding ethical concerns in medical tourism, Philosophy, Ethics and Humanities in Medicine, 8: 19 Archer, M.S. (2010). Routine, reflexivity, and realism, Sociological Theory, 28, 3, 272-303. Arellano, R. de. (2007). Patients without borders: the emergence of medical tourism. International Journal of Health Services, 37, 1, 193-198.

Arnold, J.P. (2005). Disciplining domestic regulation: the World Trade Organization and the market for professional services. Accounting, Organizations and Society, 30, 299-330. Barrowman, A., Grubor, D. and Chandu, A. (2010). Dental Implant Tourism. Australian Dental Journal, 55, 4, 441-445.

Beckert, J. (2009). The social order of markets, Theory and Society, 38, 245-269.

Bell, D., Holliday, R., Jones, M., Probyn, E., Sanchez Taylor, J. (2011). Bikinis and bandages: an itinerary for cosmetic surgery tourism. Tourism Studies, 11, 139-155.

Bell, D., Holliday, R., Ormond, M., and Mainil, T. (2015). Transnational healthcare, crossborder perspectives, Social Science \& Medicine, 124, 284-289.

Bergmann, S. (2011). Fertility tourism: Circumventing Routes that Enable Access to Reproductive Technologies. Signs: Journal of Women in Culture and Society. 36, 2, 280-289. Block, F. L. (1990). Postindustrial Possibilities: A Critique of Economic Discourse. Berkeley: University of California Press.

Bochaton, A. (2015). Cross-border mobility and social networks: Laotians seeking medical treatment along the Thai border, Social Science and Medicine, 124, 364-373.

Bolton, S.C. (2009) The lady vanishes: women's work and affective labour, International Journal of Work Organisation and Emotion, 3 (1), 72-80.

Brown, S. H. (2008). Do Mexican immigrants substitute healthcare in Mexico for health insurance in the United States? The role of distance, Social Science \& Medicine, 67, 20362042.

Buebeck, D. (2002). Justice and the Labour of Care. In E. Kittay, V.Feder, \& E. Feder (Eds.) The Subject of Care: Feminist Perspectives on Dependency. Lanham: Rowman \& Littlefield Publishers, Inc.

Buzinde, C. N. and Yarnal, C. (2012) Therapeutic landscapes and postcolonial theory: A theoretical approach to medical tourism, Social Science \& Medicine, 74, 783-787. 
Carrera, P. and Lunt, N. (2010). A European Perspective on Medical Tourism: The Need for a Knowledge Base. International Journal of Health Services, 40, 3, 469-484.

Caton, K. (2012). Taking the moral turn in tourism studies. Annals of Tourism Research, 39, 4, 1906-1928.

Chee, H. L. (2007). Medical Tourism in Malaysia: International Movement of Healthcare Consumers and the Commodification of Healthcare, Asia Research Institute, Working Paper Series No. 83

Cohen, E. (2012). Medical Travel and the Quality-of-Life. In M. Uysal et al. (Eds) Handbook of Tourism and Quality-of-Life Research (pp.169-191) Netherlands: Springer.

Connell, J. (2006). Medical tourism: Sea, sun, sand and ... surgery, Tourism Management, 27, 1093-1100.

Connell, J. (2011). Medical tourism. Wallingford, Boston: CABI.

Connell, J. (2015). From medical tourism to transnational health care? An epilogue for the future, Social Science and Medicine, 124, 398-401

Connelly Carmatt, J. (2010) Human Rights, Care Ethics and Situated Human Norms, Antipode, 43, 2: 296-325.

Cook, P. (2008). What is health and medical tourism? The annual conference of the Australian Sociological Association. 2 to 5 December 2008. The University of Melbourne, Victoria. Cortez, N. (2008). Patients Without Borders: The Emerging Global Market for Patients and the Evolution of Modern Healthcare, Indiana Law Journal, 39, 71-132.

Crush, J., Chikanda, A. and Maswikwa, B. (2012). Patients without Borders: Medical Tourism and Medical Migration in Southern Africa. Southern African Migration Programme (SAMP). Crush, J., Chikanda, A. (2015). South-South medical tourism and the quest for health in southern Africa, Social Science and Medicine, 124, 313-320

Doyal, L.(1979). The Political Economy of Health. London: Pluto Press.

Eissler, L.A. (2010). The Lived Experience of Seeking Healthcare through International Medical Tourism: An Interpretive Phenomenological Study of Alaskan Patients Traveling Internationally for Medical and Dental Care, Ph.D. Dissertation. University of Hawaii at Manoa.

Fineman, M. (2004). The Autonomy Myth: A Theory of Dependency. New York: The New Press.

Fineman, M. (2005). Cracking the Foundational Myths. In M. Fineman and T. Dougherty (Eds.), Feminism confronts homo economicus (pp.179-192). Ithaca: Cornell University Press. Fineman, M. (2008). The Vulnerable Subject: Anchoring Equality in the Human Condition, 
Yale Journal of Law and Feminism, 20, 1, 1-24.

Fletcher, R. (2011). Sustaining Tourism, Sustaining Capitalism? The Tourism Industry's Role in Global Capitalist Expansion, Tourism Geographies: An International Journal of Tourism Space, Place and Environment, 13,3, 443-461.

Gabriel, Y. (2009). Reconciling an ethic of care with critical management pedagogy, Management Learning, 40, 379-384.

Garcia-Altes, A. (2005). The Development of Health Tourism Services, Annals of Tourism Research, 32, 1, 262-265.

Gilligan, C. (1982). In a Different Voice. Massachusetts, USA: Harvard University Press. Gilmartin, M. and White, A. (2011). Interrogating Medical Tourism: Ireland, Abortion, and Mobility Rights, Sings: Journal of Women in Culture and Society, 36, 2, 275-280.

Glinos, I.A., Baeten, R.., Helble, M. and Maarse, H. (2010). A typology of cross-border patient mobility, Health \& Place, 16, 1145-1155.

Granovetter, M. (1985). Economic action and social structure: the problem of embeddedness. The American Journal of Sociology 91, 3, 481-510.

Hall, C. M. (2011). Health and medical tourism: a kill or cure for global public health?, Tourism Review, 66, 1/2, 4-15.

Halwani, R. (2003). Care Ethics and Virtue Ethics. Hypatia, 18, 3, 161-92.

Hanefeld, J., Lunt, N., Smith, R., Horsfall, D., (2015). Why do medical tourists travel to where they do? The role of networks in determining medical travel, Social Science and Medicine, 124, 356-363.

Hassan, T. (2008). An Ethic of Care Critique. Women Studies Programme. http://dspace.sunyconnect.suny.edu/bitstream/handle/1951/43954/An_Ethic_of_Care_Critique .pdf;jsessionid=A6E2C4B403A32897C04FD76A09BEE59E? sequence=1 (accessed June, 2013).

Held, V. (2006). The Ethics of Care: Personal, Political and Global. Oxford: Oxford University Press.

Holliday, R. and Elfving-Hwang, J. (2012). Gender, Globalization and Aesthetic Surgery in South Korea, Body and Society, 18, 58-81.

Horton, S. and Cole, C. (2011) Medical returns: Seeking health care in Mexico, Social Science \& Medicine, 72, 1846-52.

Hopkins, L. (2013). Out of Canada: A Personal Experience of Bariatric Surgery. In R. Labonté, V., Runnels, C., Packer, C. and R., Deonandan, (Eds.) Travelling well: Essays in medical tourism (pp. 119-132). Transdisciplinary Studies in Population Health Series, 4, 1, 
Ottawa: Institute of Population Health, University of Ottawa.

Horowitz, M. D., Rosenweig, J. A., \& Jones, C. A. (2007). Medical tourism: globalization of the healthcare marketplace. Medscape General Medicine, 9(4), 33-50.

Inhorn, M. C. and Shrivastav, P. (2010). Globalization and Reproductive Tourism in the United Arab Emirates, Asia-Pacific Journal of Public Health, 22, 3, 68S-74S.

Johnston, R., Crooks, V. A. and Snyder, J. (2012). “I didn’t even know what I was looking for": A qualitative study of the decision-making processes of Canadian medical tourists.

Globalization and Health, 8, 23, 1-12.

Johnston, R., Crooks, V. A. and Snyder, J. (2013). Exceptional Aspects of the Experiences of Canadian Medical Tourists from Patient Narratives. In R. Labonté, V. Runnels, C. Packer, and R. Deonandan (Eds.) Travelling well: Essays in medical tourism (pp.103-118).

Transdisciplinary Studies in Population Health Series, 4, 1, Ottawa: Institute of Population Health, University of Ottawa.

Kangas, B. (2011). Complicating Common Ideas about Medical Tourism: Gender, Class, and Globality in Yemenis' International Medical Travel, Signs: Journal of Women in Culture and Society, 36, 2, 327-332.

Kittay, E. (1999). Love's Labor: Essays on Women, Equality and Dependency. New York: Routledge.

Kittay, E. and Feder, E. (2002). The Subject of Care: Feminist Perspectives on Dependency. New York: Rowman and Littlefield Publishers.

Krippner, G. and Granovetter, M. (2004). Polanyi symposium: a conversation on embeddedness. Socio-Economic Review 2, 1, 109-135.

Kumar, R. (2009). Global trends in health and medical tourism. New York: SBS Publishers. Langley, P. (2007). Uncertain subjects of Anglo-American financialization. Cultural Critique, 65(1), 67-91.

Lawson, V. (2009) Instead of Radical Geography, How about Caring Geography?, Antipode, $41,1,210-213$.

Locke, J. (1689). Two Treatise of Government. Cambridge: Cambridge University Press.

Lunt, N., Smith, R., Exworthy, M., Green, S. T., Horsfall D. and Mannion R. (2011). Medical Tourism: Treatments, Markets and Health System Implications: A scoping review. Directorate for Employment, Labour and Social Affairs, OECD.

Lynch, K., Baker, J. and Lyons, M. (2009). Affective Equality: Love, Care and Injustice. London: Palgrave.

McKelvey, A., David, A.L., Shenfield. F., and Jauniaux, E. R. (2009). The impact of cross- 
border reproductive care or 'fertility tourism' on NHS maternity services. BJOG,116, 15201523

Mainil, T., Platenkamp, V. and Meulemans, H. (2011). The Discourse of Medical Tourism in the Media, Tourism Review, 66, 1/2, 31-44.

Mainil, T., Van Loon, F., Dinnie, K., Botterill, D., Platenkampf, V. and Herman Meulemans, H. (2012) Transnational health care: From a global terminology towards transnational health region development, Health Policy 108, 37-44.

Malpass, A.; Barnett, C.; Clarke, N. and Cloke, P. (2007). Problematizing Choice: Responsible consumers and sceptical citizens. In: Bevir, Mark and Trentmann, Frank (eds). Governance, Consumers and Citizens: Agency and Resistance in Contemporary Politics. Basingstoke, UK: Palgrave MacMillan, pp. 231-256.

Marx, K. and Engels, F. (2005). The Communist Manifesto: A Road Map to History's Most Important Political Document, Haymarket Books.

Mason, A. \& Wright, K. B. (2011) Framing Medical Tourism: An Examination of Appeal, Risk, Convalescence, Accreditation, and Interactivity in Medical Tourism Web Sites. Journal of Health Communication: International Perspective, 16, 2, 163-177.

Matorras, R. (2005). Reproductive exile versus reproductive tourism, Human Reproduction, $20,12,3571-3573$.

Mol, A. (2008) The Logic of Care: Health and the Problem of Patient Choice. London:

Routledge.

Musa, G., Thirumoorthi, T., and Doshi, D. (2011) Travel behaviour among inbound Medical Tourists in Kuala Lumpur, Current Issues in Tourism, 15, 6, 525-543

Niechajev, I. and Frame, J. (2012). A Plea to Control Medical Tourism, Aesthetic Plastic Surgery, 36, 202-206.

Nussbaum, M. C. (2001). Upheavals of Thought. Cambridge: Cambridge University Press.

Olson, E and Sayer, A. (2009) Radical Geography and its Critical Standpoints: Embracing the Normative, Antipode, 41, 1,180-198.

Ormond, M. and Sothern, M. (2012). You, too, can be an international medical traveller:

Reading medical travel guidebooks, Health \& Place, 18, 935-941.

Ormond, M. (2013). Neoliberal Governance and International Medical Travel in Malaysia, Routledge: Oxfordshire.

Ormond, M. and Sulianti, D. (2014). More than medical tourism: lessons from Indonesia and Malaysia on South-South intra-regional medical travel, Current Issues in Tourism Ormond, M. (2015). Solidarity by demand? Exit and voice in international medical travel: the 
case of Indonesia, Social Science and Medicine, 124, 305-312.

Penney, K., Snyder, J., Crooks, V.A. and Johnston, R. (2011) Risk communication and informed consent in the medical tourism industry: A thematic content analysis of Canadian broker websites. BMC Medical Ethics, 12, 17, 1-9.

Perfetto, R. and Dholakia, N. (2010). Exploring the cultural contradictions of medical tourism, Consumption Markets \& Culture, 13, 4, 399-417.

Polanyi K. (1957). The Great Transformation. New York: Rhinehart.

Sander-Staudt (2006). The Unhappy Marriage of Care Ethics and Virtue Ethics, Hypatia, 21, 4, 21-39.

Sayer, A. (2011). Why Things Matter to People. Cambridge: Cambridge University Press. Slote, M. (1998). Caring in the Balance. In J.Haber and S.Halfron (Eds.) Essays on the work of Virginia Held, Lanham, Md: Rowman and Littlefield

Smith-Morris, C., \& Manderson, L. (2010). The baggage of health travelers. Medical anthropology, 29, 4, 331-335.

Sobo, E.J., Herlihy, E. and Bicker, M. (2011) Selling medical travel to US patient-consumers: the cultural appeal of website marketing messages. Anthropology and Medicine, 18, 1, 119-36. Song, P. (2010). Biotech Pilgrims and the Transnational Quest for Stem Cell Cures, Medical Anthropology: Cross-Cultural Studies in Health and Illness, 29, 4, 384-402.

Skountridaki, L. (2015) The Internationalisation of Healthcare and Business Aspirations of Medical Professionals, Sociology, 49 (3), pp. 471-487.

Stiglitz, J. (2009). Interview to Amitabh Pal, The Progressive. October 2009 issue (http://progressive.org/pal1009.html, last retrieved 14 June 2013)

Streeck, W. (2011). Taking Capitalism Seriously: towards an instititutionalist approach to contemporary political economy, Socio-Economic Review, 9, 137-67.

Su, Y., Hall, M., and Ozanne, L. (2013). Hospitality Industry Responses to Climate Change: A Benchmark Study of Taiwanese Tourist Hotels, Asia Pacific Journal of Tourism Research, 18, 1-2, 92-107.

Svantesson, D.J. (2008). From the Airport to the Surgery to the Courtroom - Private International Law and Medical Tourism, Commonwealth Law Bulletin, 34, 2, 265-276. The Roestone Collective (2014) 'Safe Spae: towards a reconceptualization', Antipode, 46, 5: 1346-1365

Tribe, J. (2009). Philosophical Issues in Tourism. Bristol, Buffalo, Toronto: Channel View Publications.

Tribe, J. (2010). Tribes, territories, and networks in the tourism academy. Annals of Tourism 
Research, 28, 7-33.

Tronto, J. (1993). Moral Boundaries: A political argument for an ethic of care. New York:

Routledge.

Turner, L. (2008). Cross-border dental care: 'dental tourism' and patient mobility, British Dental Journal, 204, 10, 553-554.

Viladrich and Baron-Faust (2014). Medical tourism in tango paradise The internet branding of cosmetic surgery in Argentina, Annals of Tourism Research, 45, 116-131.

Wallerstein, I. (1974). The Rise and Future Demise of the World Capitalist System: Concepts for Comparative Analysis, Comparative Studies in Society and History, 16, 4, 387-415.

Wallerstein, I. (2002). New Revolts against the System, New Left Review, 18.

Wilson, A. (2011). Foreign Bodies and National Scales: Medical Tourism in Thailand, Body and Society, 17, 121-137.

Yeates, N. (2012). Global care chains: a state-of-the-art review and future directions in care transnationalization research, Global Networks, 12, 2, 135-154. 